Perbal: Jurnal Pertanian Berkelanjutan

Volume 10 No.1 Februari 2022

ISSN 2302-6944,e-ISSN2581-1649

\title{
ANALISIS FAKTOR-FAKTOR YANG MEMPENGARUHI ALIH FUNGSI LAHAN SAWAH KE PERKEBUNAN KELAPA SAWIT (Elaeis guineensis Jacq.) DI DESA POLONGAAN KECAMATAN TOBADAK KABUPATEN MAMUJU TENGAH
}

\author{
Analysis of Factors Affecting the Transfer of Functions of Rice Land to Oil Palm \\ Plantations (Elaeis guineensis Jacq.) in Polongaan Village, Tobadak District, Mamuju \\ Tengah Regency

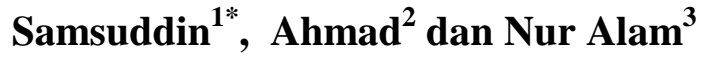 \\ Jurusan Agribisnis, Universitas Tomakaka Mamuju, Jl Ir. H Juanda No. 77, Mamuju \\ ${ }^{1) 2)}$ Pengajar Jurusan Agribisnis Fakultas Pertanian UNIKA \\ ${ }^{3)}$ Alumni Jurusan Agribisnis Fakultas Pertanian UNIKA \\ ${ }^{1 *}$ assyamsaleh@gmail.com, ${ }^{2)}$ Ahmaddian214@gmail.com, ${ }^{3)}$ nuralamfaperta96@gmail.com
}

\begin{abstract}
ABSTRAK
Tujuan penelitian ini adalah untuk menganalisis faktor-faktor apa saja yang mempengaruhi alih fungsi lahan sawah menjadi perkebunan kelapa sawit di Desa Polongaan Kecamatan Tobadak Kabupaten Mamuju Tengah. Penelitian ini dilakukan di Desa Polongaan Kecamatan Tobadak Kabupaten Mamuju Tengah dengan jumlah sampel 45 responden menggunakan purposive sampling. Hasil penelitian menunjukkan bahwa faktor-faktor yang mempengaruhi perubahan penggunaan lahan di Desa Polongaan Kecamatan Tobadak Kabupaten Mamuju Tengah adalah pendidikan, pendapatan, usia dan luas tanah. Hasil uji statistik menunjukkan bahwa koefisien regresi variabel bebas tingkat pendidikan $(\mathrm{X} 1=0,003)$, pendapatan $(\mathrm{X} 2=0,002)$, luas tanah $(\mathrm{X} 3=-0,010)$ dan usia $(\mathrm{X} 4=-0,001)$ sedangkan koefisien regresi (konstan) adalah -0,239 sehingga persamaan regresi diperoleh hasil persamaan koefisien regresi sebagai berikut: $\mathrm{Y}=-0,239+0,003 \mathrm{X} 1+0,002 \mathrm{X} 2+-0,010 \mathrm{X} 3-0,001 \mathrm{X} 4$. Berdasarkan hasil analisis uji-t, faktor pendapatan berpengaruh sangat signifikan terhadap konversi perkebunan kelapa sawit di Desa Polongaan Kecamatan Tobadak Kabupaten Mamuju Tengah dengan membandingkan sig t dengan alpha $(0,05)$ masing-masing variabel bebas. Hasil analisis uji-F terlihat bahwa nilai F-hitung lebih besar dari pada F-tabel dengan nilai signifikansi 0,05 . Hal ini menunjukkan bahwa variabel bebas (pendidikan, pendapatan, usia dan luas tanah) secara bersama-sama berpengaruh terhadap alih fungsi lahan di Desa Polongaan Kecamatan Tobadak Kabupaten Mamuju Tengah.
\end{abstract}

Kata Kunci : alih fungsi, sawah, kelapa sawit

\begin{abstract}
The purpose of this study was to analyze what factors influenced the conversion of paddy fields to oil palm plantations in Polongaan Village, Tobadak District, Central Mamuju Regency. This research was conducted in the Polongaan Village, Tobadak District, Central Mamuju Regency with a sample size of 45 respondents using purposive sampling. The results of the study showed that the factors affecting land use change in Polongaan Village, Tobadak District, Mamuju Tengah Regency were education, income, age and land area. Statistical test results show that the regression coefficient of the independent variable education level $(X 1=0.003)$, income $(X 2=0.002)$, land area $(X 3=-0.010)$ and age $(X 4=-0.001)$ while the regression coefficient (constant) is -0.239 so regression equations obtained the results of the regression coefficient equation as follows: $Y=-0.239+0.003 X 1+0.002 X 2+$ $-0.010 X 3-0.001 X 4$. Based on the results of the t-test analysis, the income factor has a very significant influence on the conversion of oil palm plantations in the Polongaan Village, Tobadak District, Mamuju Tengah Regency by comparing sig t to alpha (0.05) of each independent variable. The results of the F-test analysis show that it appears that the F-calculated value is greater than the F-table with a significant value of 0.05. This shows that the independent variables (education, income, age and land area) jointly affect the transfer of land functions in Polongaan Village, Tobadak District, Mamuju Tengah Regency.
\end{abstract}

Keywords: transfer function, paddy field, palm 
Perbal: Jurnal Pertanian Berkelanjutan

Fakultas Pertanian Universitas Cokroaminoto Palopo

\section{PENDAHULUAN}

Kabupaten Mamuju Tengah terus mengalami perluasan perkebunan kelapa sawit dari tahun ke tahun. Data Badan Pusat Statistik (2011) menyebutkan bahwa lahan perkebunan kelapa sawit di Mamuju Tengah pada tahun 2012 seluas 11.644,21 hektar, kemudian pada tahun 2014 bertambah 3.000 hektar.

Laju penggunaan lahan di Kabupaten Mamuju Tengah pada perkebunan sawit di tahun 2005 hanya mencapai 18 persen lalu meningkat 36 persen pada 2011 dan meningkat cukup pesat pada tahun 2016 mencapai 64 persen di Kabupaten Mamuju Tengah. Perluasan lahan sawit tersebut tidak dapat dibendung sehingga berdampak pada konversi lahan sawah di Desa Palongaan yang sebagai sentra produksi beras di Kecamatan Tobadak (Badan Pusat Statistik Mamuju Tengah, 2011).

Lahan pertanian menjadi aset terpenting petani di pedesaan tempat mereka berusahatani. Pilihan komoditas yang dibudidayakan oleh petani didasarkan pada pilihan rasional dengan berbagai pertimbangan. Oleh karena itu, tidak jarang petani melakukan alih fungsi dari satu jenis tanaman ke jenis tanaman lainnya pada lahan pertaniannya (Badan Pusat Statistik Mamuju Tengah, 2011).

Faktor alih fungsi lahan menjadi penting diketahui pertanian tanaman pangan seperti padi yang dapat mengancam ketahanan pangan baik secara lokal, regional, maupun nasional. Saat ini di Desa Polongaan Kecamatan Tobadak Kabupaten Mamuju Tengah cukup luas alih fungsi lahan pangan ke perkebunan khususnya kelapa sawit sehingga tujuan penelitian tersebut untuk mengetahui faktor-faktor apa saja yang secara signifikan mendorong petani melakukan alih fungsi lahan (Badan Pusat Statistik Mamuju Tengah, 2011).

Salah satu dampak konversi lahan sawah yang sering menjadi sorotan masyarakat luas adalah terganggunya ketahanan pangan. Masalah yang ditimbulkan bersifat permanen atau tetap akan terasa dalam jangka panjang meskipun konversi lahan sudah tidak terjadi lagi (Irawan dan Friyatno, 2002).

Fauzi (2005) menyatakan bahwa terjadinya alih fungsi lahan sawah antara lain disebabkan karena kurangnya kepastian harga padi sehingga pendapatan yang diperoleh dari pertanian tanaman padi lebih kecil dibandingkan dengan usaha perkebunan kelapa sawit. 


\section{METODE PENELITIAN}

Penelitian dilaksanakan di Desa Polongaan Kecamatan Tobadak Kabupaten Mamuju Tengah pada bulan Oktober Sampai November 2019. Penentuan lokasi Penelitian ini menggunakan pendekatan deskriptif kuantitatif untuk memberikan gambaran tentang suatu daerah, masyarakat, kelompok tentang satu gejala dan hubungan diantara gejala atau lebih (Suhartono, 2008). Menganalisis faktor-faktor apa saja yang menyebabkan alih fungsi lahan sawah ke perkebunan kelapa sawit (Elaeis guineensis Jacq.) di Desa Polongaan Kecamatan Tobadak Kabupaten Mamuju Tengah. Pemilihan lokasi penelitian berdasarkan pertimbangan bahwa di Desa Polongaan merupakan salah satu sentra produksi padi di Kecamatan Tobadak namun sudah banyak yang beralih fungsi ke lahan perkebunan sawit. Populasi dalam penelitian ini adalah masyarakat di Desa Polongaan sebanyak 2.867 Kepala Rumah Tangga. Teknik penentuan sampel dengan cara Purposive Random Sampling. Teknik penentuan sampel dilakukan dengan menggunakan rumus Slovin (Notoatmodjo, S. 2010) yaitu sebanyak 45 orang.

Analisis data yang digunakan dalam penelitian ini adalah analisis regresi sederhana untuk mengetahui gambaran faktor alih fungsi lahan dan analisis kuantitatif melalui uji-T dan uji-F adalah sebagai berikut (Irianto, 2004)

$$
Y=a+b X
$$

Untuk mendapatkan nilai a dan $b$ digunakan rumus sebagai berikut :

$$
\begin{aligned}
& a=\frac{\left(\sum Y\right) \cdot\left(\sum X^{2}\right)-\left(\sum X\right) \cdot\left(\sum X Y\right)}{n \cdot\left(\sum x^{2}\right)-\left(\sum x\right)^{2}} \\
& b=\frac{n \sum X Y-\sum X \sum Y}{n \cdot\left(\sum X^{2}\right)-\left(\sum X\right)^{2}}
\end{aligned}
$$

Keterangan:

$$
\begin{aligned}
\mathrm{X}= & \text { variabel independen (faktor-faktor) } \\
\mathrm{Y}= & \text { variabel dependen (alih fungsi } \\
& \text { lahan) } \\
\mathrm{a}= & \begin{array}{l}
\text { konstanta, perpotongan garis pada } \\
\text { sumbu } \mathrm{Y}
\end{array} \\
\mathrm{b}= & \text { koefisien regresi }
\end{aligned}
$$

\section{HASIL DAN PEMBAHASAN}

Faktor-faktor yang Mempengaruhi Alih Fungsi Lahan di Desa Polongaan

Hasil analisis uji statistik menunjukkan bahwa koefisien regresi untuk variabel bebas tingkat pendidikan $\left(\mathrm{X}_{1}=0,003\right)$, pendapatan $\left(\mathrm{X}_{2}=0,002\right)$, luas lahan $\left(X_{3}=-0,010\right)$ dan usia $\left(X_{4}=-0,001\right)$ sedangkan koefisien regresi (constant) sebesar -0,239 sehingga apabila dimasukkan dalam persamaan regresi akan diperoleh hasil persamaan koefisien regresi sebagai berikut : $Y=-0,239+0,003 X_{1}+0,002 X_{2}$ $+-0,010 \mathrm{X}_{3}-0,001 \mathrm{X}_{4}$.

Hasil penelitian yang menunjukkan bahwa biaya produksi berpengaruh positif 
Perbal: Jurnal Pertanian Berkelanjutan

Fakultas Pertanian Universitas Cokroaminoto Palopo

terhadap terdinya alih fungsi lahan tanaman

pangan padi sawah ke sektor perkebunan

kelapa sawit ini didukung oleh penelitian sebelumnya yang dilakukan oleh Ashari (2004) membuktikan secara empirik pengaruh biaya produksi terhadap terjadinya alih fungsi lahan pertanian sawah ke sektor non-sawah di Pulau Jawa.

Menurut Kasdi Subagyono dalam Pasaribu, 2011:155, dampak lain dari konversi lahan antara lain adalah:

1. Berkurangnya lahan pertanian produktif.

2. Menurunnya produksi dan produktivitas tanaman (khususnya tanaman pangan).

3. Terganggunya potensi dan ketersediaan sumber daya air.

4. Ketahanan pangan

\section{Pengujian secara Parsial ( Uji-t )}

Uji $t$ untuk membuat kesimpulan mengenai pengaruh paling dominan dari masing - masing variabel independen $(\mathrm{X})$ terhadap variabel $(Y)$. Pengujian bertujuan untuk mengetahui apakah koefisien regresi signifikan atau tidak signifikan. Jika thitung > dari pada t-tabel, maka variabel bebas mempunyai pengaruh yang signifikan atau nyata terhadap variabel bebas, dengan memperbandingkan nilai t-hitung dengan memberikan derajat bebas 0,05 .

Uji-t dilakukan untuk mengetahui apakah secara parsial faktor tingkat pendidikan $\left(\mathrm{X}_{1}\right), \quad$ variabel tingkat pendapatan $\left(\mathrm{X}_{2}\right)$, usia $\left(\mathrm{X}_{3}\right)$ dan variabel luas lahan $\left(\mathrm{X}_{4}\right)$, berpengaruh secara signifikan terhadap alih fungsi lahan (Y) di Desa Polongaan Kecamatan Tobadak Kabupaten Mamuju Tengah yaitu dengan membandingkan sig t dengan alpha $(0,05)$ dari tiap-tiap variabel bebas.

\section{Pendidikan $\left(\mathrm{X}_{1}\right)$}

Hasil uji statistik analisis regresi menunjukkan bahwa koefisien regresi untuk variabel bebas tingkat pendidikan berpengaruh positif di angka $\left(X_{1}=0,003\right)$. Semakin tinggi tingkat pendidikan petani maka semakin rendah alih fungsi lahan yang terjadi di Desa Polongaan dengan nilai t-hitung sebesar $0,803<$ nilai t-tabel 2,119 dan nilai signifikan sebesar 0,435> 0,05 sehingga dapat disimpulkan bahwa $\mathrm{H}_{0}$ diterima dan $\mathrm{H}_{1}$ ditolak. Hal ini memperlihatkan bahwa pendidikan $\left(\mathrm{X}_{1}\right)$ tidak berpengaruh secara signifikan terhadap alih fungsi lahan (Y).

\section{Pendapatan $\left(\mathbf{X}_{2}\right)$}

Hasil uji statistik analisis regresi menunjukkan bahwa koefisien regresi untuk variabel bebas tingkat pendapatan berpengaruh positif di angka $\left(X_{2}=0,002\right)$. Pendapatan sawit yang tinggi dari pendapatan petani padi menyebabkan alih fungsi lahan sawah ke perkebunan kelapa 
sawit Desa Polongaan dengan nilai t-hitung sebesar 4.489> nilai t-tabel 2,119 dan nilai signifikan sebesar $0,000<0,05$. Maka dapat disimpulkan bahwa $\mathrm{H} 0$ ditolak dan $\mathrm{H} 1$ diterima. Pendapatan $\left(\mathrm{X}_{2}\right)$ berpengaruh secara signifikan terhadap alih fungsi lahan (Y), dimana pendapatan petani padi sebelum mengalihfungsikan lahan sawahnya rata-rata sebesar Rp.6.000.000/musim/ha, sedangkan pendapatan petani sawit/tahun/ha sebesar Rp.11.245.167.00. Lahan sawah tadah hujan di Desa polongan menyebabkan lahan sawah tersebut hanya bisa ditanami pada musim penghujan saja atau hanya setahun sekali.

\section{Luas Lahan $\left(\mathbf{X}_{3}\right)$}

Hasil uji statistik analisis regresi menunjukkan bahwa koefisien regresi untuk variabel luas lahan berpengaruh negatif di angka $\left(X_{3}=-0,010\right)$ terhadap alif fungsi lahan. Tanda negatif berarti semakin luas lahan sawah yang dimiliki oleh petani, maka semakin besar alih fungsi lahan yang dilakukan di Desa Polongaan dengan nilai thitung sebesar $-0.216<$ nilai t-tabel 2,119 dan nilai signifikan sebesar 0,797 >0,005. Berdasarkan hal ini, maka dapat disimpulkan bahwa H0 diterima dan H1 ditolak. Luas lahan $\left(\mathrm{X}_{3}\right)$ tidak berpengaruh secara signifikan terhadap alih fungsi lahan (Y).

Persaingan terjadi untuk pemanfaatan yang paling menguntungkan sehingga dapat mendorong terjadinya perubahan pemanfaatan lahan (Kustawan dalam Saili dan Purwadio, 2012:1). Sihalo dalam (Astuti, 2011:8) menjelaskan bahwa konversi lahan adalah alih fungsi lahan pertanian ke penggunaan non pertanian atau dari lahan non pertanian kelahan pertanian. Iqbal dan Soemaryanto, dalam Lestari (2011:2) mengatakan bahwa ahli fungsi (konversi) lahan adalah merupakan perubahan spesifik dari penggunaan untuk pertanian bagi non pertanian. Sedangkan menurut Ruswandi, dalam Lestari (2011:2) mendefinisikan bahwa konversi lahan adalah berubahnya satu penggunaan lahan ke penggunaan lainnya, sehingga permasalahan yang ditimbulkan akibat konversi lahan banyak terkait dengan kebijakan tataguna tanah.

\section{Usia $\left(\mathrm{X}_{4}\right)$}

Hasil uji statistik analisis regresi menunjukkan bahwa koefisien regresi untuk variabel usia berpengaruh positif di angka $\left(\mathrm{X}_{4}=0,001\right)$. Semakin tinggi usia petani maka akan semakin tinggi pula alih fungsi lahan di Desa Polongaan dengan nilai thitung sebesar $-0,202<$ nilai t-tabel 2,119 
Perbal: Jurnal Pertanian Berkelanjutan

Fakultas Pertanian Universitas Cokroaminoto Palopo

dan nilai signifikan sebesar $0,842>0,05$ dapat disimpulkan bahwa $\mathrm{H}_{0}$ diterima dan $\mathrm{H}_{1}$ ditolak. Usia petani $\left(\mathrm{X}_{4}\right)$ tidak berpengaruh secara signifikan terhadap alih fungsi lahan (Y).

Alih fungsi lahan yang dilakukan di Desa Polongaan rata-rata sebesar $75 \%$ dari laus lahan yang dimilikinya. Jenis lahan sawah yang dialihfungsikan petani didominasi oleh sawah pasang surut yang hanya digenangi oleh air ketika intensitas hujan tinggi, sedangkan jenis sawah tadah hujan juga ikut dialihfungsikan petani karena desa Polongaan beriklim tropis dan curah hujan yang kecil dan tidak dapat mengairi padi dengan baik.

\section{Pengujian secara Simultan (Uji-F)}

Uji F pada dasarnya dilakukan untuk menunjukkan seberapa jauh pengaruh semua variabel terikat. Dalam penelitian ini juga dilakukan uji $\mathrm{F}$ untuk membuktikan apakah secara bersama-sama faktor pendidikan $\left(\mathrm{X}_{1}\right)$, pendapatan $\left(\mathrm{X}_{2}\right)$, luas lahan $\left(\mathrm{X}_{3}\right)$ dan usia $\left(\mathrm{X}_{4}\right)$ berpengaruh signifikan terhadap alih fungsi lahan (Y) di Desa Polongaan Kecamatan Tobadak Kabupaten Mamuju Tengah, yaitu dengan melihat jika nilai F-hitung > F-tabel maka variabel independen secara simultan berpengaruh terhadap variabel dependen dan sebaliknya dengan nilai signifikan 0,05.

\section{KESIMPULAN}

Berdasarkan hasil pembahasan dapat disimpulkan bahwa hasil pengujian secara parsial (uji-t) yang terlihat bahwa faktor pendapatan sangat berpengaruh signifikan terhadap alih fungsi lahan sawah ke perkebunan kelapa sawit. Hasil uji $\mathrm{F}$ untuk membuktikan bahwa secara bersama-sama faktor pendidikan $\left(\mathrm{X}_{1}\right)$, pendapatan $\left(\mathrm{X}_{2}\right)$, luas lahan $\left(\mathrm{X}_{3}\right)$ dan usia $\left(\mathrm{X}_{4}\right)$ berpengaruh signifikan terhadap alih fungsi lahan (Y) di Desa Polongaan Kecamatan Tobadak Kabupaten Mamuju Tengah, yaitu dengan melihat jika nilai F-hitung $>\mathrm{F}$ tabel maka variabel independen secara simultan berpengaruh terhadap variabel dependen dan sebaliknya dengan nilai signifikan 0,05.

\section{DAFTAR PUSTAKA}

Astuti, D. (2011). Keterkaitan Harga Lahan terhadap Laju Konversi Lahan Pertanian di Hulu Sungai Ciliung Kabupaten Bogor, Bogor. IPB.

Ashari, S. (2004). Biologi Reproduksi Tanaman Buah-buahan Komersial. Bayumedia Publishing, Malang

Badan Pusat Statistik [BPS] Provinsi Sulawesi Barat.. (2011). Provinsi Sulawesi Barat dalam Angka 2010. BPS Provinsi Sulawesi Barat 2011.

Fauzi, Y. (2005). Perbandingan Produktivitas Padi dan Tanaman Perkebunan. 
http://www.bulog.org/cons.htm. diakses pada 11-03-2019.

Irawan, B. dan S. Friyatno. (2002). Dampak konversi lahan sawah di Jawa terhadap produksi beras dan kebijakan pengendaliannya. Jurnal Sosial-Ekonomi Pertanian dan Agribisnis. SOCA: 2(2) : 79-95.

Irianto, K. (2004). Struktur dan Fungsi Tubuh Manusia untuk Paramedis. Yrama Widya. Bandung.

Lestari, A. (2011). Dampak sosio-ekonomis dan sosio-ekologis konversi lahan. Jurnal Sosiologi Pedesaan. Vol 5, No. 1. Bogor : IPB. (online) Diunduh 06-03-2019.

Notoatmodjo, S. (2010). Metodologi Penelitian Kesehatan. Rineka Cipta. Jakarta.

Pasaribu M. (2011). Konversi dan Fragmentasi Lahan Ancaman terhadap Kemandirian Pangan. Badan Litbang Pertanian. Jakarta.

Saili, I. dan Purwadio, H. (2012). Pengendalian alih fungsi lahan pertanian sawah menjadi perkebunan kelapa sawit diwilayah Kabupaten Siak, Riau. Teknik Perencanaan Wilayah dan Kota. Vol 1. No. 1. Surabaya : ITS. (online) diakses pada 02-13-2019.

Suhartono, S. (2008). Wawasan Pendidikan: Sebuah Pengantar Pendidikan. ArRuzzmedia. Yogyakarta. 